\title{
SH3PXD2B wt Allele
}

National Cancer Institute

\section{Source}

National Cancer Institute. SH3PXD2B wt Allele. NCI Thesaurus. Code C119650.

Human SH3PXD2B wild-type allele is located in the vicinity of 5q35.1 and is approximately $129 \mathrm{~kb}$ in length. This allele, which encodes SH3 and PX domain-containing protein 2B, plays a role in podosome assembly. Mutation of the gene is associated with Frank-Ter Haar syndrome. 